\title{
Diversity and abundance of wild birds species' in two different habitats at Sharkia Governorate, Egypt
}

\author{
Mohamed Abd Allah Issa(i)
}

\begin{abstract}
Background: Birds' survey is the best method to understand different species distribution, abundance, and diversity. The present study aimed to survey wild birds, using point count method, in two habitat types (water canals and field crops) at two districts, Zagazig and Hehia, located at Sharkia Governorate, Egypt.
\end{abstract}

Methods: Surveying birds was conducted using point count method, from a fixed raising position within a circle of $50 \mathrm{~m}$ radius for a specific period of time $(10 \mathrm{~min})$ at every point. It started early in the morning, from $6 \mathrm{am}$ to $8 \mathrm{am}$, at four points in two habitat types, agriculture water canals habitat (AWCH) and field crops habitat (FCH), in (Zagazig and Hehia) at Sharkia Governorate, Egypt. Each point count was visited once every month from December 2016 to November 2017.

Results: The total number of birds' species recorded in the two districts was 33, belonging to 24 Families and ten Orders. Twenty-five species were resident birds and eight species were migratory. The number of birds' species (resident and migratory) in AWCH was higher than those in FCH. Resident wild birds at AWCH had higher value of species diversity (Shannon-Weiner Diversity Index $H^{\prime}=2.63$, Simpson Diversity Index $D=0.90$, Evenness $J^{\prime}=0.82$ and Species richness $r=25)$ than at $F C H\left(H^{\prime}=2.56, D=0.89, J^{\prime}=0.83\right.$, and $\left.r=22\right)$. In contrast, species diversity for migratory wild bird was lower in WCH $\left(H^{\prime}=1.66, D=0.74, J^{\prime}=0.80\right.$, and $\left.r=8\right)$ than in FCH $\left(H^{\prime}=1.81, D=0.78, J^{\prime}=0.87\right.$, and $\left.r=8\right)$.

Conclusion: Birds species (resident and migratory) numbers and abundance were higher in AWCH according to the habitat suitability than in FCH.

Keywords: Wild bird, Survey, Point count method, Water canals, Habitat, Crops, Diversity index, Resident, Migratory

\section{Background}

Egypt is located at the Northeastern corner of Africa and occupies an area of about one million kilometer. It enjoys a unique strategic location, at the crossroads between Africa, the Middle East, and Europe. Egypt is divided into four physiographical regions: Nile Valley and Delta, Western Desert, Eastern Desert, and Sinai. The country is rich in wild bird species due to its wide range of habitats. Egypt is a "centralized" zone of wild bird migration pathways from Central Asia and Europe to Eastern and Central Africa expiration in South Africa (Soliman, Saad, Elassal, Amir, Plathonoff, Bahgat, El-Badry, \& Mohamed. 2012). About 515 birds species

\footnotetext{
Correspondence: mohamedissa011@gmail.com

Plant Protection Research Institute, Agricultural research Center, Dokki, Giza, Egypt
}

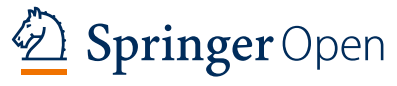

(c) The Author(s). 2019 Open Access This article is distributed under the terms of the Creative Commons Attribution 4.0 International License (http://creativecommons.org/licenses/by/4.0/), which permits unrestricted use, distribution, and reproduction in any medium, provided you give appropriate credit to the original author(s) and the source, provide a link to the Creative Commons license, and indicate if changes were made. gratory (Tharwat, 1997). At Ismailia Governorate, 27 resident wild bird species, belonging to 20 families and nine orders, were recorded, while migratory birds were six species that belonged to five families and three orders (Abbasy, Mostafa, Khattab, El-Danasory, \& Attia, 2011; Attia, 2013). Sharkia Governorate is a home of many wild bird species. Khattab (1998) recorded 23 resident species and eight migratory species. Attia (2006) recorded 25 resident species belonging to nine orders and 21 families, and 26 migratory species belonging to six orders and 15 families. Population density and species diversity of birds is differing, increasing or decreasing according to habitat type and richness.

This study aimed to investigate the abundant, distribution, and diversity of wild bird species, in two different 
habitats within two districts (Zagazig and Hehia), at Sharkia Governorate, and their probable impact on agriculture.

\section{Materials and methods Study areas}

Sharkia Governorate is located at the eastern site of the Nile Delta. It covers about 1,200,000 feddans (1 feddan $=4200 \mathrm{~m}^{2}$ ), one million of them is cultivated with different field crops and fruit orchards. Desert and swampland, with their different preferred birds habitats, are located to the eastern and southern borders of this governorate.

Data was collected from two districts; Hehia $\left(30^{\circ} 67^{\prime} \mathrm{N}\right.$, $\left.31^{\circ} 59^{\prime} \mathrm{E}\right)$ and Zagazig $\left(30^{\circ} 60^{\prime} \mathrm{N}, 31^{\circ} 51^{\prime} \mathrm{E}\right)$. Two main habitats were chosen in each district:

1- Agriculture water canal habitat $(\mathrm{AWCH})$ : this site was around and beside main agricultural water canals, where dense vegetation, shrubs, and high trees usually located. Different field crop lands, cultivated with wheat, alfalfa, and onion in winter, maize and rice in summer, are nearby. Very low human settlements and activities are in this habitat.

2- Filed crops habitat (FCH): including the main agricultural fields planted with different traditional crops (wheat, alfalfa, and onion in the winter and maize and rice in summer) with some scattered palm trees. Farmers' houses and animal farms are adjacent to this habitat, with considerable human activities.

\section{Field methods}

Field data were obtained using the "point counts" method, which is a count from a fixed location, for a fixed time period, at any time of the year. This method is suitable for studying highly visible, and/or vocal bird species, in a wide variety of habitats (Gibbons, Hill, \& Sutherland, 1996). In this study, birds were counted from a fixed raising position within a circle of $50 \mathrm{~m}$ radius for a specific period of time $(10 \mathrm{~min})$ at every point. After 5-min settling period, all birds seen and heard within this $50 \mathrm{~m}$ radius were recorded during the $10 \mathrm{~min}$. Bird counts were carried out early in the morning, from 6 am to 8 am, at two points in each habitat within each district (four points at Zagazig and four points at Hehia). Each point count was visited once every month from December 2016 to November 2017 (Bibby, Burgess, Hill, \& Mustoe, 2000; Haselmayer \& Quinn, 2000; Lande, 1996). No detected windy or rainy conditions during the days of this study. A binocular $(10 \times 50)$ was used to confirm species identity. Proofs of identifications were done using Collins Bird Guide (Svensson, Mullarney, Zetterström, \& Grant, 2009).
Species were assigned to families and orders according to Clements, Schulenberg, Iliff, Roberson, Fredericks, Sullivan, and Wood (2018).

\section{Data analysis}

Data were arranged to obtain the following parameters:

I) The relative abundance of bird species per habitat/ district was determined using:

$$
\text { Relative abundance }=\frac{n}{N}
$$

where $n$ is the total number of birds of a particular species and $N$ is the total number of birds of all species.

II) Bird species diversity:

Species richness is the number of different species present in an area (Deitmers, Buehler, Bartlett, \& Klaus, 1999). Species richness was estimated for each habitat.

Shannon-Weiner Index $\left(H^{\prime}\right)$ was calculated in order to know the species diversity (Hutcheson, 1970) based on species abundance using the Shannon and Weaver (1949) formula:

$$
H^{\prime}=-\left[\sum \mathrm{Pi}^{*} \mathrm{LN}(\mathrm{Pi})\right]
$$

where $H^{\prime}$ is the Diversity Index, $\mathrm{Pi}$ is the proportion of each species in the sample, and $\mathrm{LN}(\mathrm{Pi})$ is the natural logarithm of this proportion.

Evenness of birds species compares the similarity of the population size of each species. Evenness Index $\left(J^{\prime}\right)$ (Kiros, Afework, \& Legese, 2018) was calculated using the ratio of observed diversity to maximum diversity using the equation.

$$
J^{\prime}=\frac{H^{\prime}}{H_{\max }}
$$

where $H^{\prime}$ is the Shannon Wiener Diversity index and $H_{\text {max }}$ is the natural log of total number of species.

Simpson Index $(D)$ measures the probability of any two individuals drawn from noticeably large community belonging to different species (Simpson, 1949). It was measured by the following formula:

$$
D=1-\frac{\sum \mathrm{n}(n-1)}{N(N-1)}
$$

where $n$ is the total number of birds of a particular species and $N$ is the total number of birds of all species. 


\section{Results and discussion}

\section{Wild bird species records}

The structure of birds communities recorded at Sharkia Governorate was varied. The checklist in Table 1 showed wild bird species recorded in the two different habitats (AWCH and FCH) at Zagazig and Hehia districts; Sharkia Governorate, during the period from December 2016 to November 2017.

The obtained data showed that the total number of wild bird species found was 33, with 25 resident and eight migratory, belonging to 24 Families and ten Orders. Order Passeriformes was the dominant one represented by 13 families including 15 species, four migratory, and 11 residents. Order Coraciiformes was in the second rank with two families including five species, two residents, and three migratory. Order Pelecaniformes represented by one family with two resident and two migratory species. While the lowest orders in numbers were Accipitriformes, Bucerotiformes, Cuculiformes, Falconiformes, and Gruiformes, which is represented by one species for each.

Table 1 Wild birds species recorded from the two districts; Zagazig and Hehia, at Sharkia governorate

\begin{tabular}{|c|c|c|c|c|}
\hline Order & Family & English name & Species & Status \\
\hline Accipitriformes & Accipitridae & Black-winged kite & Elanus caeruleus & $\mathrm{R}$ \\
\hline Bucerotiformes & Upupidae & Hoopoe & Upupa epops & $\mathrm{R}$ \\
\hline Chardriiformes & Burhinidae & Senegal thick-knee & Burhinus senegalensis & $\mathrm{R}$ \\
\hline$"$ & Charadriida & Spur winged plover & Vanellus spinosus & $\mathrm{R}$ \\
\hline Columbiformes & Columbidae & Rock dove & Columba livia & $\mathrm{R}$ \\
\hline$"$ & $"$ & Palm dove & Streptopelia senegalensis & $\mathrm{R}$ \\
\hline Coraciiformes & Alcedinidae & Kingfisher & Alcedo atthis & M \\
\hline$"$ & $"$ & Pied kingfisher & Ceryle rudis & $\mathrm{R}$ \\
\hline$"$ & $"$ & White throated kingfisher & Halcyon smyrnensis & M \\
\hline$"$ & Meropidae & Blue-cheeked bee-eater & Merops persicus & M \\
\hline$"$ & $"$ & Little green bee eater & Merops orientalis & $\mathrm{R}$ \\
\hline Cuculiformes & Cuculidae & Senegal coucal & Centropus senegalensis & $\mathrm{R}$ \\
\hline Falconiformes & Falconidae & Kestrel & Falco tinnunculus & $\mathrm{R}$ \\
\hline Gruiformes & Rallidae & Moorhen & Gallinula chloropus & $\mathrm{R}$ \\
\hline Passeriformes & Acrocephalidae & Clamorous reed warbler & Acrocephalus stentoreus & $\mathrm{R}$ \\
\hline$"$ & Alaudidae & Crested lark & Galerida cristata & $R$ \\
\hline$"$ & Cisticolida & Zitting cisticola & Cisticola junicides & $\mathrm{R}$ \\
\hline$"$ & $"$ & Graceful prinia & Prinia gracilis & $R$ \\
\hline$"$ & Corvidae & Hooded crow & Corvus cornix & $\mathrm{R}$ \\
\hline$"$ & Estrildidae & Red avadavat & Amandava amandava & $\mathrm{R}$ \\
\hline$"$ & Hirundinidae & Barn swallow & Hirundo rustica & $\mathrm{R}$ \\
\hline$"$ & Motacillidae & White wagtail & Motacilla alba & M \\
\hline$"$ & $"$ & Yellow wagtail & Motacilla flava & $\mathrm{R}$ \\
\hline$"$ & Muscicapidae & Bluethroat & Luscinia svecica & M \\
\hline$"$ & Passeridae & House sparrow & Passer domesticus & $\mathrm{R}$ \\
\hline$"$ & Ploceidae & Streaked weaver & Ploceus manyar & $\mathrm{R}$ \\
\hline$"$ & Phylloscopidae & chiffchaff & Phylloscopus collybita & M \\
\hline$"$ & Pycnonotidae & Common bulbul & Pycnonotus barbatus & $R$ \\
\hline$"$ & Sylviidae & Lesser whitethroat & Sylvia curruca & M \\
\hline Pelecaniformes & Ardeidae & Cattle egret & Bubulcus ibis & $R$ \\
\hline " & $"$ & Little egret & Egretta garzetta & $\mathrm{R}$ \\
\hline$"$ & $"$ & Black-crowned night heron & Nycticorax nycticorax & $\mathrm{R}$ \\
\hline$"$ & $"$ & Squacco heron & Ardeola ralloides & M \\
\hline
\end{tabular}

$R$ resident birds species, $M$ migratory birds species 
Relative abundance of resident wild bird species

Resident wild bird species numbers were presented in Table 2 for both habitats. In the AWCH, the following species were recorded in a descending order: House sparrow, Hooded crow, Rock dove, Palm dove, and Cattle egret. Their numbers were the highest as follows: $1133,575,538,528$, and 462 individuals, respectively. Their relative abundances were $0.214,0.108,0.102$, 0.099 , and 0.087 , respectively. The lowest number of birds was eight individuals with relative abundance of 0.001, for black-winged kite.

In the $\mathrm{FCH}$, the highest birds number was the House sparrow followed by Palm dove, Hooded crow, Rock dove, Cattle egret, and Graceful prinia in a descending order as follows: 817, 403, 384, 318 and 193 individuals and relative abundance of: $0.230,0.113,0.108,0.089$, and 0.054 , respectively. The Black-crowned night heron number was the lowest, with 6 individuals and 0.002 relative abundance.

\section{Relative abundance of migratory wild bird species}

The data in Table 3 demonstrated the numbers and relative abundance of migratory wild bird species in $\mathrm{AWCH}$ and $\mathrm{FCH}$ at Sharkia governorate. In the $\mathrm{WCH}$, the following species were recorded in a descending order: White wagtail, Blue-cheeked bee-eater, Lesser whitethroat, Bluethroat, and Kingfisher. Their numbers were the highest as follows: 254, 88, 62, 49, and 40 individuals, respectively. Their relative abundances were 0.450 , $0.156,0.109,0.086$, and 0.071 , respectively. The lowest number of birds was five individuals with relative abundance of 0.008 , for chiffchaff.

In the $\mathrm{FCH}$, the highest bird number was the White wagtail followed by Lesser whitethroat, Kingfisher, White throated kingfisher and Bluethroat in a descending order as follows: $175,53,43,42$, and 39 individuals. Their relative abundances were $0.404,0.122,0.099,0.096$, and 0.090 , respectively. The lowest number and relative

Table 2 Relative abundance of resident wild birds observed at Sharkia governorate

\begin{tabular}{|c|c|c|c|c|c|c|c|c|}
\hline \multirow[t]{2}{*}{ English name } & \multicolumn{4}{|l|}{ AWCH } & \multicolumn{4}{|l|}{$\mathrm{FCH}$} \\
\hline & $\begin{array}{l}\text { Number in sample } \\
\text { (count) }\end{array}$ & $\begin{array}{l}\text { Relative abundance } \\
\text { "Pi" }\end{array}$ & $\begin{array}{l}\mathrm{LN} \\
\text { "Pi" }\end{array}$ & $\begin{array}{l}\mathrm{Pi}{ }^{*} \\
\mathrm{LN}(\mathrm{Pi})\end{array}$ & $\begin{array}{l}\text { Number in sample } \\
\text { (count) }\end{array}$ & $\begin{array}{l}\text { Relative abundance } \\
\text { "Pi" }\end{array}$ & $\begin{array}{l}\mathrm{LN} \\
{ }^{\prime \mathrm{Pi}}\end{array}$ & $\begin{array}{l}\mathrm{Pi} \text { * } \\
\mathrm{LN}(\mathrm{Pi})\end{array}$ \\
\hline Black-winged kite & 8 & 0.001 & -6.495 & -0.009 & 14 & 0.003 & -5.535 & -0.022 \\
\hline Hoopoe & 88 & 0.016 & -4.096 & -0.068 & 79 & 0.022 & -3.805 & -0.085 \\
\hline Senegal thick-knee & 39 & 0.007 & -4.910 & -0.036 & 18 & 0.005 & -5.284 & -0.027 \\
\hline Spur winged plover & 158 & 0.029 & -3.511 & -0.105 & 148 & 0.042 & -3.177 & -0.132 \\
\hline Rock dove & 538 & 0.102 & -2.286 & -0.232 & 318 & 0.089 & -2.412 & -0.216 \\
\hline Palm dove & 528 & 0.099 & -2.305 & -0.229 & 403 & 0.113 & -2.175 & -0.247 \\
\hline Pied kingfisher & 168 & 0.032 & -3.450 & -0.109 & 152 & 0.042 & -3.150 & -0.135 \\
\hline Little green bee eater & 92 & 0.017 & -4.052 & -0.070 & 53 & 0.015 & -4.204 & -0.063 \\
\hline Senegal coucal & 9 & 0.002 & -6.376 & -0.011 & 0 & 0 & 0 & 0 \\
\hline Kestrel & 82 & 0.015 & -4.167 & -0.064 & 66 & 0.018 & -3.985 & -0.074 \\
\hline Moorhen & 402 & 0.076 & -2.577 & -0.196 & 0 & 0 & 0 & 0 \\
\hline Clamorous reed warbler & 12 & 0.002 & -6.089 & -0.014 & 0 & 0 & 0 & 0 \\
\hline Crested lark & 123 & 0.023 & -3.761 & -0.087 & 89 & 0.025 & -3.685 & -0.092 \\
\hline Zitting cisticola & 119 & 0.022 & -3.795 & -0.085 & 67 & 0.018 & -3.969 & -0.075 \\
\hline Graceful prinia & 268 & 0.051 & -2.983 & -0.151 & 193 & 0.054 & -2.912 & -0.158 \\
\hline hooded crow & 575 & 0.108 & -2.219 & -0.241 & 384 & 0.108 & -2.224 & -0.240 \\
\hline Red avadavat & 40 & 0.007 & -4.885 & -0.036 & 18 & 0.005 & -5.284 & -0.026 \\
\hline Barn swallow & 132 & 0.025 & -3.691 & -0.092 & 102 & 0.028 & -3.549 & -0.102 \\
\hline Yellow wagtail & 93 & 0.017 & -4.041 & -0.071 & 68 & 0.019 & -3.955 & -0.076 \\
\hline House sparrow & 1133 & 0.214 & -1.541 & -0.329 & 817 & 0.230 & -1.468 & -0.338 \\
\hline streaked weaver & 26 & 0.005 & -5.316 & -0.026 & 7 & 0.002 & -6.228 & -0.012 \\
\hline Common bulbul & 152 & 0.028 & -3.550 & -0.102 & 184 & 0.052 & -2.959 & -0.153 \\
\hline Cattle egret & 462 & 0.087 & -2.438 & -0.213 & 318 & 0.089 & -2.412 & -0.216 \\
\hline Little egret & 36 & 0.007 & -4.991 & -0.034 & 45 & 0.013 & -4.367 & -0.055 \\
\hline Black-crowned night heron & 10 & 0.002 & -6.271 & -0.012 & 6 & 0.002 & -6.383 & -0.011 \\
\hline Total & 5293 & 1 & -99.80 & -2.63 & 3549 & 1 & -83.13 & -2.56 \\
\hline
\end{tabular}

Pi proportion of each species (relative abundance), LNPi natural logarithm of Pi 
Table 3 Relative abundance of Migratory wild bird species observed at Sharkia governorate

\begin{tabular}{|c|c|c|c|c|c|c|c|c|}
\hline \multirow[t]{2}{*}{ English name } & \multicolumn{4}{|l|}{$\mathrm{AWCH}$} & \multicolumn{4}{|l|}{$\mathrm{FCH}$} \\
\hline & $\begin{array}{l}\text { Number in sample } \\
\text { (count) }\end{array}$ & $\begin{array}{l}\text { Relative abundance } \\
\text { "Pi" }\end{array}$ & $\begin{array}{l}\mathrm{LN} \\
\text { "Pi" }\end{array}$ & $\begin{array}{l}\mathrm{Pi}{ }^{*} \\
\mathrm{LN}(\mathrm{Pi})\end{array}$ & $\begin{array}{l}\text { Number in sample } \\
\text { (count) }\end{array}$ & $\begin{array}{l}\text { Relative abundance } \\
\text { " } \mathrm{Pi}^{\prime \prime}\end{array}$ & $\begin{array}{l}\mathrm{LN} \\
\text { "Pi" }\end{array}$ & $\begin{array}{l}\mathrm{Pi}{ }^{*} \\
\mathrm{LN}(\mathrm{Pi})\end{array}$ \\
\hline Kingfisher & 40 & 0.071 & $\begin{array}{l}- \\
2.646\end{array}$ & -0.187 & 43 & 0.099 & $\begin{array}{l}- \\
2.309\end{array}$ & -0.229 \\
\hline $\begin{array}{l}\text { White throated } \\
\text { kingfisher }\end{array}$ & 34 & 0.060 & 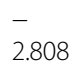 & -0.169 & 42 & 0.096 & $\overline{2} .333$ & -0.226 \\
\hline $\begin{array}{l}\text { Blue-cheeked bee- } \\
\text { eater }\end{array}$ & 88 & 0.156 & $-\overline{1.857}$ & -0.289 & 27 & 0.062 & $\overline{2} .774$ & -0.173 \\
\hline White wagtail & 254 & 0.450 & 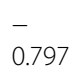 & -0.359 & 175 & 0.404 & $\overline{0} .905$ & -0.366 \\
\hline Bluethroat & 49 & 0.086 & $-\overline{2.443}$ & -0.212 & 39 & 0.090 & $-\overline{2.407}$ & -0.216 \\
\hline chiffchaff & 5 & 0.008 & $\begin{array}{l}- \\
4.725\end{array}$ & -0.041 & 30 & 0.069 & $-\overline{2} \cdot 669$ & -0.184 \\
\hline Lesser whitethroat & 62 & 0.109 & $\overline{-} .207$ & -0.242 & 53 & 0.122 & $-\overline{2}$ & -0.257 \\
\hline Squacco heron & 32 & 0.057 & - & -0.162 & 24 & 0.055 & $\overline{-} .893$ & -0.160 \\
\hline Total & 564 & 1 & - & -1.665 & 433 & 1 & $-\overline{18.39}$ & -1.814 \\
\hline
\end{tabular}

Pi proportion of each species (relative abundance), LNPi natural logarithm of $\mathrm{Pi}$

abundance was 24 individuals and 0.055 with Squacco heron.

The relative abundance of birds species in an area usually related to the availability of main life requirements (food, water and shelter) as well as suitable weather conditions. Goodman, Meininger, Bahaa El-Dine, Hoobs, and Mullie (1989) mentioned that House sparrow, Passer domesticus, Hooded crow, Corvus corone, Palm dove, Streptopelia senegalensis, and Rock dove, Columba livia were abundantly resident species in numerous portion of Egypt. White wagtail, Motacilla alba is abundant passage migrants and winter visitor to Egypt from the beginning of autumn (late September) to the end of spring (early May). Also, the Bee-eater, Merops apiaster is a common migrant throughout the country in autumn from late August to late November and spring from mid-March to late June. Attia (2006) surveyed the resident birds at Sharkia governorate in three habitats (old lands, reclaimed area, and aquatic area); he indicated that the resident birds represented in a higher value in old lands followed by aquatic area and reclaimed area while the migratory birds were highest in aquatic area followed by old lands and reclaimed area. Attia (2013) cleared that higher numbers of bird species (resident and migratory) were recorded in field crop than vegetable crop areas at Ismailia governorate. The resident wild bird species included were Crested lark, Galerida cristata, Fan tailed warbler, Cisticola juncides, Graceful warbler, Prinia gracilis, Hooded crow, Corvus corone cornix, House crow, Corvus splendens, Goldfinch, Carduelis carduelis, House sparrow, Passer domestica, Swallow,
Hirundo rustica, Yellow wagtail, Motacilla flava flava, Common bulbul, Pycnonotus babatus, Rock dove, Columba livia, Palm dove, Streptopelia senegalensis, Cattle egret, Bubulcus ibis, Little egret, Egretta garzetta, Pied kingfisher, Ceryle rudis, Little green bee-eater, Merops orientalis, Black-shouldered kite, Elanus caerulus, Kestrel, Falco tinnunculus, Spur-winged plover, Hoplopterus spenosus, Moorhen, Gallinula chloropus, Senegal coucal, Centropus senegalensis, and Hoopoe, Upupa epops. While he recorded six bird species as migratory birds: White wagtail, Motacilla alba alba, Chiffchaff, Phelloscobus collybita, Stonechat, Saxicola torquata, and Kingfisher, Alcedo atthis. Noura-Barakat (2016) illustrated that the number of bird species in Tanta district at Gharbia governorate were highest in field crops, followed by trees, water canals, and building, while in Zifta district, were in water canals, trees, building, and field crops. The resident wild birds at Gharbia governorate were Senegal thick knee, Spur-winged plover, Cattle egret, Little egret, Squacco heron, Palm dove, Pied kingfisher, Senegal coucal, Kestrel, Moorhen, Crested lark, Fan tailed warbler, Graceful warbler, Hooded crow, Swallow, Yellow wagtail, House sparrow, Common bulbul, and Hoopoe, while the white wagtail was migratory. ElDanasoury, Khalifa, Omar, and Saber (2017) surveyed the resident and migratory bird species at Assiut governorate. The birds were found in a highly numbers in the fields nearby trees, while they were found in moderate numbers in fields nearby building and field crops. The resident birds were House sparrow, Hooded crow, Crested lark, Common bulbul, Fan tailed warbler, 
Swallow, Palm dove, Rock dove, Little green bee eater, Hoopoe, Pied kingfisher, Cattle egret, Spur winged plover, Kestrel, and Black winged kite. The migratory birds were White wagtail and chiffchaff. El-Danasoury, Omar, and Hassan (2018) surveyed wild bird species at Sohag governorate; they found that the resident wild birds were Black winged kite, cattle egret, Common bulbul, Fantailed warbler, Hoopoe, Kestrel, Spur winged plover, Swallow, Yellow wagtail, Crested lark, Hooded, House sparrow, Little green bee, Moorhen, Palm dove, Pied kingfisher, and Rock dove. The migratory bird species were chiffchaff and White wagtail.

\section{Birds species diversity}

Species diversity is the number of species and abundance of each species that live in a specific location. A diversity index is a quantitative measure of how many different species are in a community (species richness) and how individuals are distributed within those species (species abundant) (You, Vasseur, Régnière, \& Zheng, 2009). Therefore, Diversity Index is considered as a calculation of variety, which is a useful tool to understand the profile of biodiversity across study area (Bibi \& Ali, 2013).

\section{Diversity indices for resident and migratory wild bird species in two different habitats}

Table 4 demonstrated some parameters associated with diversity of wild bird species at two different habitats. The total number of resident bird species at AWCH was 5293 individuals, which is higher than FCH (3549 individuals). Also, species richness in AWCH was $r=25$, which is also higher than $\mathrm{FCH}(r=22)$. At the same trend, AWCH had the highest values of Shannon-Weiner diversity index $\left(H^{\prime}\right.$ $=2.63)$ and Simpson's Diversity $(D=0.90)$, than FCH $\left(H^{\prime}=\right.$ $2.56)$ and $(D=0.89)$. While evenness $\left(J^{\prime}\right)$ were higher in $\mathrm{FCH}\left(J^{\prime}=0.83\right)$ than AWCH $\left(J^{\prime}=0.82\right)$.

The same trend existed in migratory bird species, which represented by higher numbers of individuals (564) at AWCH while at FCH was 433 individuals. Species richness was the same in AWCH and FCH $(r=8)$. But in contrast, the $\mathrm{FCH}$ give the higher values of Shannon-Weiner diversity index $\left(H^{\prime}=1.81\right)$, Simpson's

Table 4 Diversity indices for resident and migratory wild birds at Sharkia governorate

\begin{tabular}{llllll}
\hline Diversity Index & \multicolumn{2}{l}{ Resident species } & & \multicolumn{2}{c}{ Migratory species } \\
\cline { 2 - 3 } & AWCH & FCH & & AWCH & FCH \\
\hline Overall abundance & 5293 & 3549 & & 564 & 433 \\
Species richness $(r)$ & 25 & 22 & & 8 & 8 \\
Evenness $\left(J^{\prime}\right)$ & 0.82 & 0.83 & & 0.80 & 0.87 \\
Shannon-Weiner $\left(H^{\prime}\right)$ & 2.63 & 2.56 & & 1.66 & 1.81 \\
Simpson diversity $(D)$ & 0.90 & 0.89 & & 0.74 & 0.78 \\
\hline
\end{tabular}

Diversity $(D=0.78)$, and evenness $\left(J^{\prime}=0.87\right)$, than AWCH with, Shannon-Weiner diversity index $\left(H^{\prime}=1.66\right)$, Simpson's Diversity $(D=0.74)$, and evenness $\left(J^{\prime}=0.80\right)$.

\section{Diversity indices for the total numbers of wild birds in two different habitats}

The data in Table 5 evinced that the AWCH give the highest values of diversity index, the total number of birds species were (5857) individuals, species richness $(r=33)$, Shannon-Weiner diversity index $\left(H^{\prime}=2.85\right)$, and Simpson's Diversity $(D=0.92)$, while in $\mathrm{FCH}$, the total number were (3982) individuals, species richness $(r=30)$, Shannon-Weiner diversity index $\left(H^{\prime}=2.82\right)$, and Simpson's Diversity $(D=0.91)$. In contrast, evenness $\left(J^{\prime}\right)$ were higher in FCH $\left(J^{\prime}=0.83\right)$ than in AWCH $\left(J^{\prime}=0.81\right)$.

These results were in line with Mengesha and Bekele (2008). They mentioned that the avian diversity is an indication of habitat heterogeneity and the number of species and individuals in an area implies the importance of the area. Each habitat has a specific set of microenvironment that is suitable for a species. Bibi and Ali (2013) cleared that the values of Shannon-Weiner Diversity Index usually falls between 1.5 and 3.5, only rarely it surpasses 4.5. Kiros et al. (2018) mentioned that the variation in bird species diversity, richness, and abundance associated with the vegetation composition that make changes in food sources, nesting, and protection based on birds' habitat preference and feeding.

\section{Conclusion}

It is concluded from the present study that birds species varied among the study sites and between habitats. Birds species (resident and migratory) numbers and abundance were higher in AWCH according to the habitat suitability, which support free water and abundant food supply (insects, grasses, and aquatic fauna) as well as nesting and resting sites. Also, most migratory birds feed on insects. On the other hand, the $\mathrm{FCH}$ is an agriculture area with several seasonal and daily human activities, during the day hours and part of the night, which disturbs birds. Additionally, the structure of $\mathrm{AWCH}$, which include many trees and shrubs, make it a protective cover for different bird species from predators as black-winged kite, which was recorded with a higher

Table 5 Diversity indices of wild birds at Sharkia governorate

\begin{tabular}{lll}
\hline Diversity Index & AWCH & FCH \\
\hline Overall abundance & 5857 & 3982 \\
Species richness $(r)$ & 33 & 30 \\
Evenness $\left({ }^{\prime}\right)$ & 0.81 & 0.83 \\
Shannon-Weiner ( $\left.H^{\prime}\right)$ & 2.85 & 2.82 \\
Simpson diversity $(D)$ & 0.92 & 0.91 \\
\hline
\end{tabular}


numbers at $\mathrm{FCH}$ than $\mathrm{AWCH}$. The order Passeriformes was the dominant order related to its wide range of species and food types (omnivorous, insectivorous, frugivorous and granivorous). Therefore, furthermore studies of the species of this order are required in Egypt, to measure their impact on agriculture crops and to develop safe methods of crop-protection.

\section{Recommendation}

Based on the obtained results, it is clear that the majority of recorded birds species were granivorous attacking field crops. Therefore, there is an urgent need to study different species' habitat requirements, behavior, and influence on agriculture crops. This information, from this work and from future studies, can help in the development of a successful integrated birds management program to protect affected agriculture crops from birds attack.

\section{Abbreviations}

AWCH: Agriculture water canals habitat; D: Simpson Diversity Index; FCH: Filed crops habitat; H': Shannon Wiener Diversity Index; J': Evenness; M: Migratory bird species; R: Resident bird species; r: Species richness

\section{Acknowledgements}

Author acknowledge Prof. Dr. Ali H El-Sherbiny, professor of Ecology, Plant Protection Research Institute, for his helpful assistance in manuscript writing.

\section{Funding}

No funding was provided.

\section{Availability of data and materials}

All data are available upon request.

\section{Authors' contributions}

The final manuscript was read and approved by the author.

\section{Ethics approval and consent to participate}

Not applicable.

\section{Consent for publication}

Not applicable.

\section{Competing interests}

The author declares that he has no competing interests.

\section{Publisher's Note}

Springer Nature remains neutral with regard to jurisdictional claims in published maps and institutional affiliations.

Received: 21 February 2019 Accepted: 8 April 2019

Published online: 17 May 2019

\section{References}

Abbasy, M. R. A., Mostafa, M. A., Khattab, M. M. D., El-Danasory, M. A. M., \& Attia, M. A. I. (2011). Survey and seasonal fluctuation of wild birds in different locations at Ismailia Governorate. Al Azhar Journal of Agricultural Research, 11, 97-108.

Attia, M. A. I. (2006). Ornithological studies on some dominant species under the different Agroecsystems at Sharkia governorate, (p. 157). M.Sc. Thesis, Fac. Agric., Al - Azhar Univ. http://thesis.mandumah.com/Record/265866.

Attia, M. A. I. (2013). Studies on some wild bird species at Ismailia governorate, (p. 205). Ph. D. Thesis Faculty of Agric. Al-Azhar Univ. http://thesis.mandumah. $\mathrm{com} /$ Record/265849.

Bibby, C. J., Burgess, N. D., Hill, D. A., \& Mustoe, S. H. (2000). Bird census techniques. Second edition. London: Academic Press.
Bibi, F., \& Ali, Z. (2013). Measurement of diversity indices of avian communities at Taunsa Barrage Wildlife Sanctuary, Pakistan. The Journal of Animal \& Plant Sciences, 23(2), 469-474

Clements, J. F., Schulenberg, T. S., Iliff, M. J., Roberson, D., Fredericks, T. A., Sullivan, B. L., Wood, C. L. (2018). The eBird /Clements checklist of birds of the world: Website URL: ttp://www.birds.cornell.edu/clementschecklist/download/v2018.

Deitmers, R., Buehler, D. A., Bartlett, J. G., \& Klaus, N. A. (1999). Influence of point count length and repeated visits on habitat model performance. The Journal of Wildlife Management, 63(3), 815-823.

El - Danasoury, M. A. M., Khalifa, H. M. S., Omar, M. M. A., \& Saber, M. A. (2017). General survey of some wild bird species in new reclaimed areas of tow districts at Assiut governorate, (Upper Egypt ). Minia Journal of Agricultural Research and Development, 37(1), 35-44.

El - Danasoury, M. A. M., Omar, M. M. A., \& Hassan, A. A. G. (2018). Survey of some wild birds in Akhmim and Tahta districts at Sohag governorate. Academia Journal of Agricultural Research, 6(5), 060-064.

Gibbons, D.W., Hill, D., \& Sutherland, W.J. (1996). Birds. In Ecological census techniques: a handbook, ed. WJ. Sutherland, pp. 227-259. Cambridge University Press.

Goodman, S. M., Meininger, P. L., Bahaa El-Dine, S. M., Hoobs, J. J., \& Mullie, W. C. (1989). The birds of Egypt. New York: Univ. Oxf.

Haselmayer, J., \& Quinn, J. S. (2000). A comparison of point counts and sound recording as bird survey methods in Amazonian Southeast Peru. Condor, 102, 887-893.

Hutcheson, K. (1970). A test for comparing diversities based on the Shannon formula. Journal of Theoretical Biology, 29, 151-154.

Khattab, M. M. (1998). Ecological studies on some wild bird species at Sharkia governorate, (p. 192). Ph. D. Thesis Faculty of Agric., Al - Azhar Univ.

Kiros, S., Afework, B., \& Legese, K. (2018). A preliminary study on bird diversity and abundance from Wabe fragmented forests around Gubre subcity and Wolkite town, southwestern Ethiopia. International Journal of Avian \& Wildlife Biology, 3(5), 333-340.

Lande, R. (1996). Statistics and partitioning of species diversity and similarity among multiple communities. Oikos, 76, 5-13.

Mengesha, G., \& Bekele, A. (2008). Diversity and relative abundance of birds of Alatish National Park, North Gondar, Ethiopia. International Journal of Ecology and Environmental Sciences, 34(2), 215-222.

Noura-Barakat, M. E. (2016). Ecological and biological studies on some wild bird species at Gharbia governorate, (p. 180). M.Sc.Thesis Fac. Agric., Al - Azhar Univ.

Shannon, C. E., \& Weaver, W. (1949). The mathematical theory of communication (p. 144). Urbana: University of Illinois Press.

Simpson, E. H. (1949). Measurement of diversity. Nature, 163, 688

Soliman, A., Saad, M., Elassal, E., Amir, E., Plathonoff, C., Bahgat, V., ... Barthel, R. (2012). Surveillance of avian influenza viruses in migratory birds in Egypt, 2003-2009. Journal of Wildlife Diseases, 48(3), 669-675.

Svensson, L., Mullarney, K., Zetterström, D., \& Grant, P. J. (2009). Collins bird guide. Second edition. London: Harper Collins.

Tharwat, M. E. (1997). Birds known to occur in Egypt. Cairo: Publication of National biodiversity, Unit. No. 8, 1997, EEAA, El-Walid Press.

You, M., Vasseur, L., Régnière, J., \& Zheng, Y. (2009). The three dimensions of species diversity. The Open Conservation Biology Journal, 3, 82-88.

\section{Submit your manuscript to a SpringerOpen ${ }^{\circ}$ journal and benefit from:}

- Convenient online submission

- Rigorous peer review

- Open access: articles freely available online

- High visibility within the field

- Retaining the copyright to your article

Submit your next manuscript at $\boldsymbol{\nabla}$ springeropen.com 